\title{
The Effect of Organizational Culture, Job Stress and Job Characteristics on Employee Performance in Padang Tourism and Culture Office
}

\author{
Rini firtria ${ }^{1}$ Sulastri ${ }^{2}$ \\ ${ }^{1}$ Universitas Negeri Padang, Padang, Indonesia \\ ${ }^{2}$ Universitas Negeri Padang, Padang, Indonesia, $₫$ sulastri.feunp@gmail.com
}

\begin{abstract}
This study aims to analyze the effect of organizational culture, work stress and job characteristics on employee performance. The sample of this study was 41 employees who worked in Padang Tourism and Culture Office. The analysis technique used in this study is SEM Partial Least Square (PLS) analysis. The results showed that organizational culture has no significant effect on employee performance, organizational culture has a negative and significant effect on employee work stress, job characteristics have a positive and significant effect on employee performance, job characteristics have no significant effect on employee work stress, work stress has a negative and significant effect on employee performance, organizational culture does not have a significant effect on employee performance through work stress, and job characteristics do not significantly effect on employee performance through the work stress.
\end{abstract}

Keywords: Organizational culture; Job Stress; Job Characteristics; Employee Performance

\section{Introduction}

Employee performance is very important thing for an organization. Organizational goals will be achieved if human resources show high work performance. Performance is a description of the level achievement of an activity program or policy in realizing the goals, objectives, vision and mission of the organization as outlined through the strategic planning of an organization. Hasibuan (2012) argues that performance is the result of work achieved by someone.

Some previous studies are still inconsistencies in the results of the research conducted. The results of the Pamungkas (2016) research show that employee performance is not influenced by organizational culture but is influenced by job characteristics. In contrast to the results of research conducted by Cahyana (2018), it shows that performance is influenced by organizational culture, job stress and job satisfaction. Meanwhile the results of the Frismandiri (2015) study show that performance does not have an influence on job characteristics. From some of the results of previous studies, the author interested to analyze the influence of organizational culture, job characteristics and work stress on performance.

Organizational culture is one of the factors that can affect employee performance. Organizational culture affects organizational members, communicate, and behave in work, and affects employee performance at work. The relationship of performance can be seen that culture creates high motivation and job satisfaction. Robbins (2010) says organizational culture is a system of shared understanding by members of an organization that distinguishes the organization from other organizations. Organizational culture is shared values and beliefs that allow members to understand their role in the organization and organizational norms.

Organizational culture is important when there is awareness that the existence of a strong organizational culture can be a strong foundation for the organization to achieve vision and mission. Conducting organizational culture and supporting the creation of maximum work results will result in high or maximum employee performance (Rivai, 2012).

Other factors that also affect employee performance are job characteristics. Job characteristics are related to how employees assess tasks in their work. Hackman and Odham in Robbins (2008) developed a motivational approach to design work by using a model of job characteristics approach which is referred to as the theory of job characteristics. Job characteristics in the job characteristics 
model show that any work can be described in five core dimensions, namely diversity of skills, task identity, task significance, autonomy, and feedback. Good organization needs to pay attention to job characteristics and organizational commitment to achieve organizational goals effectively and efficiently.

Job characteristics are the basis for employee productivity and performance designed to acheve important role in the success and survival of the company. In conditions of increasing competition, well-designed work will be able to attract and retain workers and provide motivation to produce products and services quality.

Job stress is an important aspect for the company, especially for employee performance. Job stress is a condition where there are one or several factors in the workplace that interact with workers that interfere with physiological conditions, and behavior.

Stress has positive and negative effects. The impact of positive stress at a low level to moderate levels is functional for improving employee performance. While the negative impact of high levels of stress is a decrease in drastic employee performance. When an employee or manager is able to manage stress, the consequence is functional (positive effect), on the contrary if ignoring the stress that arises, the consequences are negative effect for individuals and organizations. So, stress not only has a negative impact, but also has a positive impact.

According to Robbins (2008), there are several factors that influence work stress including excessive workload, pressure, unfavorable work environment, job responsibilities, work design, and lack of career advancement. The psychological impact of work stress experienced by a person can cause anxiety, depression and decreased performance.

The difference between this research and previous research is on the object used. The object used in this study is the Department of Tourism and Culture of Padang City which is located at Jl. Gandaria No. 56 Padang. Padang Tourism and Culture Office is one of the Regional Organizations (OPD) in the City of Padang.

Starting from the phenomena and the results of previous research, Author need to examine the problems of employee performance with the title of the research is "Effect of Organizational Culture, Job Stress and Job Characteristics on Employee Performance in Padang Tourism and Culture Office ".

\section{Methods}

Based on research objectives, this type of research can be classified as confirmatory and explanatory research. The samples in this study were all employees working in Tourism and Culture Office of Padang City with a total of totaling 41 people. The research instrument used in this study is a questionnaire to measure the variables studied by giving a Likert scale score (1-5) on the answer statement.

Hypothesis testing of this research was analyzed by the Structural Equation Model (SEM) using smart PLS software. Partial Least Square (PLS) is a structural equation model (SEM) based on components or PLS variant is an alternative approach that shifts from a covariance based SEM approach to a variant based. Covariance based SEM generally tests causality / theory while PLS is more predictive model.

\section{Results and Discussion \\ Respondent Characteristics}

Respondent characteristics seen from the demographic aspects of the respondents are based on gender, age, and education shows some interesting information. Based on the results of the respondent characteristics in this study, it shows that female respondents were 16 people $(39.02 \%)$, while those of the male were 25 people $(60.93 \%)$. This shows that the employee in Tourism and Culture Office in the Padang City are more male. Then based on age, the most age at the age range of $31-40$ years as many as 14 people (34.15\%), then at the age of $41-50$ years as many as 11 people (26.83\%), while respondents at the age above 50 years as many as 9 people $(21.95 \%)$. The smallest number of respondents based on age is at the age below 30 years as many as 7 people $(17.07 \%)$. 
Furthermore, based on the latest education, the dominant level of education is S1 (Strata-1), which is as many as 21 people $(51.22 \%), 22$ respondents with S2 (Strata-2) education $(36.59 \%)$, and as many as D3 respondents. 5 people (12.20\%). Characteristics of respondents based on the highest number of years of work in Tourism and Culture Office with more than 10 years of work as many as 15 people $(36.59 \%)$, respondents with a working period of $5-10$ years as many as 13 people $(31.71 \%)$. Furthermore, respondents with 1-5 years of work were 11 people $(26.83 \%)$. Respondents with the smallest number were based on the working period which is $<1$ year as many as 2 people $(4.88 \%)$.

\section{Description of Research Variables}

The description of the research variables explained by using the results of the calculation of the level of respondent's performance which shows the results of the respondents' answers received. The description results are explained for each research variable.

Performance variables obtained information that the average score of the performance variable is 3.96 with the respondent's achievement level (TCR) of $79.16 \%$. This shows that the performance variables are in the sufficient category. It can be said that the employee performance in Tourism and Culture Office of the Padang City still needs to be improved. The performance is assessed by quality, quantity, timeliness, effectiveness, work commitment, and interpersonal relationships. The highest average score is the employee work commitment.

Then in the organizational culture variables, information is obtained that the average score of the organizational culture variable is 3.58 with the respondent's achievement level (TCR) of $71.59 \%$. This shows that the organizational culture variables are in the sufficient category. It can be said that the organizational culture in Tourism and Culture Office of the Padang City still needs to be improved. The organizational culture in this study is seen from the organizational culture consisting of family culture, Eiffel tower culture, guided missile culture, and incubator culture. The highest average score is incubator culture but still in the sufficient category. The incubator culture still needs to be improved such as supporting employees' self-development, respecting the opinions of each employee, involving them in decision making, and having a formal organizational structure.

Job characteristics variable obtained information that the average score of the job characteristics variable was 3.78 with the respondent's achievement level (TCR) of $75.51 \%$. This shows that the job characteristics variable is in the sufficient category. It can be said that the job characteristics in Tourism and Culture Office of the Padang City still need to be improved. Job characteristics in this study are seen from the diversity of expertise (variety skills), task identity, assignment meaning (task significance), autonomy, and feedback. The highest average indicator value in the job characteristics variable is the task identity.

Job stress variables obtained information that the average score of work stress variables is 2.16 with the respondent's achievement level (TCR) of $43.25 \%$. This shows that work stress variables are in the very less category. It can be said that work stress in Tourism and Culture Office of the Padang City is still very low. Job stress in this study is seen from physiological symptoms, and psychological symptoms. The highest average indicator value is physiological symptoms.

\section{PLS analysis}

Data analysis in this study was using the Smart PLS 3.0 program. The steps taken in the analysis process include: 1) evaluation of the measurement model (outer model), to find out the relationship of the indicators that form the latent variable, and 2) the evaluation of the structural model (inner model), the purpose is to find out the relationship of the variables that make up the research model.

\section{Outer Model}

Evaluation of the measurement model (outer model), to measure the validity and reliability of these indicators are convergent validity, discriminant validity, and composite reliability and cronbach alpha. 


\section{Convergent Validity}

Model validity can be measured by convergent validity and discriminant validity. Convergent validity is measuring the indicators validity. This evaluation is examining the outer loading coefficients of each indicator against the latent variables. A valid indicator if the outer loading coefficient is between $0.60-0.70$, but for analysis whose theory is unclear then the outer loading of 0.50 is recommended.

Based on the results of outer loading, a number of items that are invalid statements because they have the value of outer loading below 0.6, namely the organizational culture variable with outer loading $-0.193-0.748$; job characteristics variable with outer loading $-0.542-0.698$; work stress variable with outer loading $0.456-0.833$; and performance variables with outer loading $0.329-0.812$. From each item statement there are 25 invalid statements so they are excluded from the research model and re-estimate the construct model so the outer loading culture results in organizational organization are obtained from 0.639 - 0.817; Job characteristics 0.729 - 0.828; work stress 0.635 - 0.891 ; performance $0.629-0.840$.

From the results of the final construct model it is known that all variable indicators have convergent validity above 0.6 so re-estimate is not needed and the final construct model is obtained.

\section{Discriminant Validity}

Discriminant Validity can also be measured by comparing the square root value of average variance extracted (AVE) of each construct with a correlation between the construct and other constructs in the model. If the AVE square root value of each construct is greater than the correlation value between constructs and other constructs in the model, it has good discriminant validity value and AVE is greater than 0.50 .

Table 1 AVE

\begin{tabular}{ll}
\hline Variables & AVE \\
\hline Organizational culture & 0.513 \\
\hline Job Characteristics & 0.572 \\
\hline Performance & 0.525 \\
\hline Work stress & 0.532 \\
\hline
\end{tabular}

Source: Data Processed Results, 2019

Table 1 shows that the AVE value seen from the whole sample original value is construct $>0.50$, so the AVE value criteria meet valid requirements based on discriminant validity criteria.

\section{Reliability}

A measurement can be said to be reliable, if the composite reliability and cronbach alpha has a value greater than 0.70 . Composite reliability and Cronbach alpha is a measurement of reliability of indicator blocks in the research model. A composite reliability calculation result on organizational culture variables is 0.839 ; job characteristics 0.842 ; work stress 0.870 ; performance of 0.929 . Then the value of Cronbach Alpha on organizational culture variables is 0.764 ; job characteristics variable 0.763 ; work stress variable 0.825 ; performance variable 0.918 . The composite reliability and Cronbach Alpha values of all constructs showed values greater than 0.70 so they meet reliable requirements based on composite reliability criteria.

\section{Structural Model/Inner Model}

R-Square (R2) can show the strength of the influence caused by the dependent variable on the independent variable. R-Square (R2) can also show the strength of a research model. The value of $R$ Square (R2) is 0.67 classified as a strong model, R-Square (R2) is 0.33 classified as a moderate model, and R-Square (R2) is 0.19 classified as a weak model. 
Table 2 R-Square

\begin{tabular}{ccc}
\hline Variables & R-Square & $\begin{array}{c}\text { R-Square } \\
\text { Adjusted }\end{array}$ \\
\hline Performance & 0.500 & 0.459 \\
\hline Work Stress & 0.260 & 0.221 \\
\hline
\end{tabular}

Source: Data Processed Results, 2019

Table 2 shows that the value of R2 from the independent variable (performance) is 0.500 , so the model is included in the strong model criteria. It means the organizational culture, job characteristics, and work stress can explain performance by 50 percent and the remaining 50 percent explained by variations of other variables.

\section{Hypothesis testing}

Hypothesis testing was used by using the structural model (inner model) by looking at the Rsquare value. The path coefficients show the parameter coefficients and the $t$ statistical significance. The significance of the estimated parameters can provide information about the relationships between the research variables. The expected hypothesis testing is Ha accepted or sig value $<0.05$.

Table 3 Hypothesis Testing

\begin{tabular}{|c|c|c|c|c|c|}
\hline & $\begin{array}{l}\text { Original } \\
\text { Sample }\end{array}$ & $\begin{array}{c}\text { Sample } \\
\text { Mean }\end{array}$ & $\begin{array}{l}\text { Standard } \\
\text { Deviation }\end{array}$ & $\begin{array}{c}T \\
\text { statistics }\end{array}$ & $\begin{array}{c}P \\
\text { value }\end{array}$ \\
\hline $\begin{array}{l}\text { Organizational Culture - } \\
\text { Performance }\end{array}$ & 0.032 & 0.080 & 0.148 & 0.218 & 0.828 \\
\hline Organizational Culture - Job Stress & -0.426 & $\begin{array}{r}- \\
0.467\end{array}$ & 0.136 & 3.123 & 0.002 \\
\hline Job Characteristics - Performance & 0.422 & 0.412 & 0.189 & 2.235 & 0.026 \\
\hline Job Characteristics - Job Stress & -0.135 & $\begin{array}{r}- \\
0.153\end{array}$ & 0.163 & 0.828 & 0.408 \\
\hline Job Stress - Performance & -0.411 & $\begin{array}{r}- \\
0.386\end{array}$ & 0.190 & 2.158 & 0.031 \\
\hline $\begin{array}{l}\text { Organizational Culture - Job Stress - } \\
\text { Performance }\end{array}$ & 0.175 & 0.181 & 0.100 & 1.745 & 0.082 \\
\hline $\begin{array}{l}\text { Job Characteristics - Job Stress - } \\
\text { Performance }\end{array}$ & 0.055 & 0.056 & 0.079 & 0.702 & 0.483 \\
\hline
\end{tabular}

Source: Data Processed Results, 2019

The results of hypothesis testing show that there are several rejected hypotheses, namely the influence of organization culture on employee performance; the effect of job characteristics on employee work stress; indirect influence of organizational culture on employee performance through work stress; and indirect effects of job characteristics on employee performance through work stress. Based on the results of the study obtained the final model as follows: 


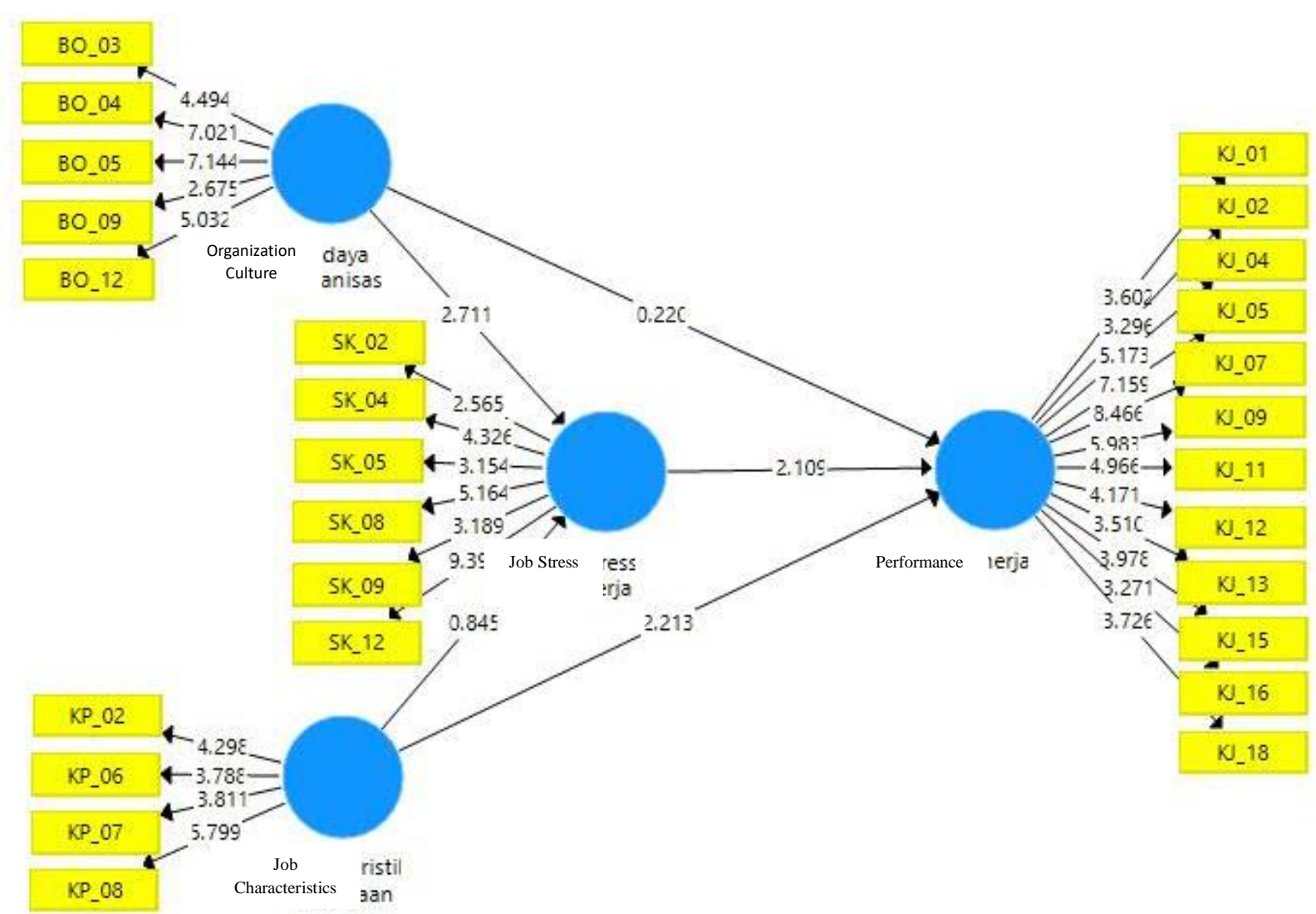

Figure 1 Final Research Model

The results of first hypothesis are known that organizational culture does not have a significant effect on the employee's performance in Tourism and Culture Office in the Padang City. The high and low organizational culture of the employee in the Tourism and Culture Office could not improve employee performance so the first hypothesis in this study was rejected. Robbins (2008) explains that organizational culture refers to a system of shared understanding by members of an organization. Organizational culture can be said as a habit that continues over and over and becomes a value and lifestyle by a group of individuals in the organization. Organizational culture can also be interpreted as a value, belief and attitude that is able to encourage members of the organization to be involved in achieving organizational goals together in a single unit. The results of the study are not in line with the results of research by Susetyo (2014) shows that organizational culture has a significant effect on performance. Luthans (2014) states that there are three aspects of organizational functions that are very important in determining organizational culture: (1) general relations between employees and their organizations, (2) systems of power hierarchy that determine the roles of managers and subordinates; and (3) the general view that employees hold their goals and targets.

The results of second hypothesis are known that organizational culture has a significant effect on work stress in Tourism and Culture Office in Padang City. The negative influence of organizational culture on job stress means that if the organizational culture increases can reduce the work stress in Padang Tourism and Culture Office staff. Schein in Ivancevich (2005), explains that organizational culture is a basic pattern created, discovered or developed by certain groups when learning to problems of external adaptation and internal integration, teach new members as the right way to perceive, think and feel in relation to the problems. If a positive organizational culture can run well by members of the organization it can reduce work stress. The results of research by Pamungkas (2016) show that organizational culture variables have an influence on work stress variables.

Luthans (2014) argues that, organizational culture is a shared values and beliefs that allow members to understand their role in the organization and organizational norms. According to Kreitner (2014) organizational culture has a function as (1) identity, shows a characteristic to 
differentiate from other organizations, (2) joint commitment about norms that must be followed in the organization to achieve common goals, (3) improve social system stability that it reflects the work environment is felt positive and strengthened, conflict and change can be managed effectively, (4) forming behavior because it can make people think healthy and reasonable. If the function is created in the organizational environment, the work stress of members will decrease.

The results of third hypothesis are known that job characteristics have a significant effect on the employee's performance in Tourism and Culture Office in the Padang City. If the job characteristics are getting better, it can improve the performance of employees in Tourism and Culture Office in the Padang City. Job characteristics are characteristics that differ from one type of work that are specific in nature which is the core of the work that contains the characteristics of the tasks that exist in all work and perceived by employees. Job characteristics are the basis for organizational productivity and employee job satisfaction is designed to play an important role in individual employee success and the survival of the organization.

Robbins (2008) describes job characteristics as an attempt to identify characteristics, tasks of work, how those characteristics are combined to different jobs, and their relationship with motivation, job satisfaction and employee performance. Jobs that intrinsically provide satisfaction will be more motivating for most people and for unsatisfactory work. If the characteristics of the work are in accordance with the skills and abilities of employees, it can improve performance. The results of research conducted by Pamungkas (2016) show that work characteristics have a positive and significant effect on employee performance. The same thing was expressed by Yuxiu (2011), job characteristics have a positive influence on performance. Kassem (2013) describes that employment characteristics consisting of variations in tasks, task significance, task identity, and task autonomy can affect performance. Managers must consider the characteristics of the job to redesign the work to improve satisfaction and performance. Johari (2015) aimed at adding feedback factors apart from the variation of tasks, task significance, task identity, and task autonomy that could affect performance. Park (2017) describes that critical psychological conditions can mediate the influence of organizational culture (task variation, task significance, task identity, task autonomy, and feedback) on performance. It is based on Evelyne's research (2018) shows that organizational culture has no significant effect on performance.

Based on the results of fourth hypothesis, job characteristics do not significantly effects on the work stress in Tourism and Culture Office in the Padang City. If the job characteristics are good, it will not affect the work stress. Job characteristics indicate how much decision making is made by employees to their jobs, and how many tasks must be completed by employees. Job characteristics are the attitude of the internal aspects of the work from the variety of skills needed, procedures and tasks, the level of task importance, authority, responsibility and feedback from the tasks. The results of this study are not in line with the results of research conducted by Pamungkas (2016) which shows that work characteristics have a positive effect on work stress.

The results of fifth hypothesis are known that work stress has a significant effect on the employee performance in Tourism and Culture Office in the Padang City. Job stress has a negative effect on performance which means the work stress increases; it can reduce employee performance so that the fifth hypothesis in this study is accepted. Mondy (2008) describes stress as a reaction from the body to the pressure. According to Ivancevich (2005) stress is an adaptive response, moderated by individual differences, which is a consequence of every action, situation or event. Moorhead (2013) argues that stress is a person's adaptive response to stimuli excessive psychological or physical demands. Stress affects each individual in different ways that condition is very dependent on the individual. The level of stress and tension that builds up in the workplace can worsen the mood of employees, causing them to experience more negative emotions. If the problem cannot be managed properly by the organization, it will affect employee performance.

Robbins (2008) suggests that stress affects emotions and moods. Stress affects each individual in different ways. The level of stress and tension that builds up in the workplace can worsen the mood of employees, causing them to experience more negative emotions. At work, daily task or task that 
occur continuously, such as a task that must be completed, work deadlines, superiors, etc. Some problems caused by work stress can affect performance. The results of research conducted by Cahyana (2018) show that work stress have a positive effect on employee performance.

Sasono (2004) stated that stress has positive and negative effects. The impact of positive stress at a low level to moderate levels is functional in the sense for improving employee performance. Based on the results of sixth hypothesis it is known that organizational culture does not have a significant effect on performance through the work stress. If the organizational culture is getting better, it will not affect performance through the work stress.

There are three aspects of organizational functions that are very important in determining organizational culture: (1) general relations between employees and their organizations, (2) systems of power hierarchy that determine the roles of managers and subordinates; and (3) the general view that employees hold their goals, targets and destiny. Greenberg in Wibowo (2016) states that organizational culture is a cognitive framework consisting of attitudes, values, norms and expectations that are shared by members of the organization. Organizational culture is a set of core characteristics that are valued collectively by members of the organization. It can be said that the organizational culture can be determined by the relationship between employees, organization hierarchy, and the general view of employees, but the culture of the organization does not affect the employee's performance through employee work stress.

The results of seventh hypothesis are known that job characteristics do not have a significant effect on performance through work stress. If the job characteristics are getting better, it will not affect performance through the work stress.

Hackman \& Oldham in Robbins (2008) explains that job characteristics are internal aspects of a work that refer to the work conditions. Job characteristics are the attitude of the internal aspects of the work from the variety of skills needed, procedures, clarity of tasks, and the level of importance of tasks, authority, responsibility and feedback from the tasks. Job characteristics can directly affect the performance of an employee, but if job characteristics do not affect performance through employee work stress.

\section{Conclusions}

Based on the results and discussion as presented in the previous chapter, some conclusions can be drawn as follows: Organizational culture has no significant effect on employee performance; Organizational culture has a negative and significant effect on employee work stress; Job characteristics have a positive and significant effect on employee performance; Job characteristics do not significantly effect on employee work stress; Job stress has a negative and significant effect on employee performance; Organizational culture has no significant effect on employee performance through work stress; Job characteristics do not have a significant effect on employee performance through the work stress in Padang City Tourism and Culture Office employees.

Based on the conclusions, there are some suggestions given to be taken: (1). Improve job characteristics by increasing employee work outcomes such as providing training, meets work with the skills and abilities of employees so that it has a large influence on the organization; Providing flexibility to employees in completing their work; Providing flexibility to employees in determining the best method in completing their work; set clear standards on work so the work provides information about how employees perform; (2). Reducing work stress by making employees comfortable in facing work deadlines; increase the concentration of work of employees; Making work more enjoyable that employees are not dizzy in doing work; eliminate laziness in work; eliminate boredom with work; creating a comfortable working atmosphere; mutual relationship with coworkers; improve work results; do not procrastinate on work; making work as a hobby so employees are not burdened with thinking about work and are not anxious in the office; (3). Improve organizational culture by choosing leaders who can be considered as mentors, role models and places to ask for opinions / guidance as well as parent figures for employees; provide input to employees that work interests are more important than individual interests; Providing equal opportunities for 
employee to occupy a position and be more objective in choosing employees to occupy positions; Give freedom to employees to make decisions and use their own methods in completing work; Supporting personal development of employees such as training and development activities for each employee; Respecting the opinions of each employee and involving them in decision making.

\section{References}

Cahyana. (2018). Pengaruh Budaya Organisasi, Stres Kerja Dan Kepuasan Kerja Terhadap Kinerja Pegawai.

Evelyne, Ngari. 2018. Job Characteristics and Employee Performance in Private Equity Firms in Kenya. IOSR Journal of Business and Management (IOSR-JBM) Volume 20, Issue 1.

Frismandiri, D. (2015). Analisis Pengaruh Karakteristik Pekerjaan, Kepuasaan Kerja dan Komitmen Terhadap Kinerja Karyawan.

Hasibuan, M. (2012). Manajemen Sumber Daya Manusia. Jakarta: Bumi Aksara.

Ivancevich. (2005). Perilaku dan Manajemen Organisasi. Jakarta: Erlangga.

Johari, Johanim. 2015. Elevating Job Performance Through Job Characteristics and Work Involvement. International Academic Research Journal of Social Science 1(2) 2015 Page 69-82

Kaseem, Hazem S. 2013. Effect of job characteristics on satisfaction and performance: A test in Egyptian agricultural extension system. African Journal of Agricultural Research Vol. 8(48), pp. 6126-6130

Kreitner, R. (2014). Perilaku Organisasi. Jakarta: Salemba Empat.

Luthans, F. (2014). Organization Behavior. New York: McGraw Hill International.

Mondy, R. W. (2008). Manajemen Sumber Daya Manusia. Jakarta: Erlangga.

Moorhead, G. (2013). Perilaku Organisasi : Manajemen SDM dan Organisasi. Jakarta: Salemba Empat.

Pamungkas. (2016). Pengaruh Budaya Organisasi, Karakteristik Kerja, dan Stres Kerja, Serta Dampaknya Pada Kinerja Pegawai (Studi Pada PT. PLN (Persero) AP2B Sistem Minahasa.

Park, Seejeen. (2017). Motivating Raters Through Work Design: Applying The Job Characteristics Model To The Performance Appraisal Context. Cogent Psychology (2017), 4

Rivai, V. (2012). Kepemimpinan dan Perilaku Organisasi. Jakarta: PT. Raja Grafindo Persada.

Robbins. (2008). Perilaku Organisasi. Jakarta: Salemba Empat.

Robbins. (2010). Manajemen. Jakarta: Erlangga.

Sasono. (n.d.). Mengelola Stres Kerja. Jurnal Fokus Ekonomi. Vol III. No.2.

Susetyo, W. (2014). Pengaruh Budaya Organisasi Dan Lingkungan Kerja Terhadap Kepuasan Kerja Dan Kinerja Karyawan Pada PT. Bank Muamalat Indonesia Divisi Konsumer Area Cabang Surabaya.

Wibowo. (2016). Budaya Organisasi : Sebuah Kebutuhan Untuk Meningkatkan Kinerja Jangka Panjang. Jakarta: Rajawali.

Yuxiu, P. (2011). Job Characteristics and Job Performance among Professional Nurses in the University Hospitals of People's Republic of China. CMU. 